\title{
Requirement Engineering terhadap Virtual Team pada Proyek Software Engineering
}

\author{
Muhammad Nasrullah $^{* 1)}$, Nisa Dwi Angresti' ${ }^{2)}$, Sayekti Harits Suryawan ${ }^{3)}$, dan Faizal \\ Mahananto $^{4)}$ \\ ${ }^{1)}$ Program Studi Sistem Informasi, Fakultas Teknologi Informasi dan Industri, Institut Teknologi Telkom \\ Surabaya, Jalan Ketintang 156, Kota Surabaya, 60231, Indonesia \\ ${ }^{2}$ Program Studi Teknologi Informasi, Politeknik Negeri Padang, Jl. Kampus, Limau Manis, Kota Padang, \\ 25164, Indonesia \\ 3) Program Studi Teknik Informatika, Fakultas Sains dan Teknologi, Universitas Muhammadiyah Kalimantan \\ Timur, Jl. Ir. H. Juanda No.15, Kota Samarinda, 75124, Indonesia \\ ${ }^{4)}$ Departemen Sistem Informasi, Fakultas Teknologi Elektro dan Informatika Cerdas, Institut Teknologi Sepuluh \\ Nopember, Jalan Raya ITS, Kota Surabaya, 60111, Indonesia \\ Email: 르nasrul@ittelkom-sby.ac.id ${ }^{11}$, nisa.dwi.angresti@gmail.com ${ }^{2}$, sayekti.harits@gmail.com $^{3)}$, \\ fmahananto@gmail.com ${ }^{4}$
}

\begin{abstract}
Abstrak
Seiring perkembangan teknologi, virtual team dapat menjadi solusi untuk sebuah proyek software engineering, karena virtual team tidak terbatas oleh letak geografis dan waktu. Namun, untuk menentukan kebutuhan pengguna dari virtual team ini menemui beberapa kendala, karena para stakeholder yang tidak saling bertatap muka, sehingga sulit untuk saling mendapatkan feeling antara stakeholder. Salah satu teknik yang digunakan untuk penggalian kebutuhan pada virtual team ini adalah teknik kolaborasi. Kolaborasi dilakukan dengan memanfaatkan berbagai media/teknologi. Tujuan literature review ini adalah mengulas cara-cara penggalian kebutuhan pada virtual team dan mengulas tantangan apa saja yang dihadapi untuk penggalian kebutuhan pada virtual team. Metode yang digunakan dalam penulisan makalah ini adalah studi literatur dari berbagai sumber pustaka yang relevan. Hasil dari studi litetatur ini adalah sebuah pemaparan tentang cara penentuan kebutuhan terhadap virtual team dan tantangan yang dihadapi dalam penggalian kebutuhan pada virtual team. Penentuan kebutuhan pada virtual team dilakukan dengan cara pendekatan user-centered design dan wawancara online. Tantangan utama dalam penentuan kebutuhan pada virtual team ini adalah komunikasi, bahasa, budaya, dan perbedaan waktu.
\end{abstract}

Kata kunci: Virtual Team, Software Engineering, Penggalian Kebutuhan, Kolaborasi.

\section{Pendahuluan (Introduction)}

Software requirements adalah suatu bentuk definisi kebutuhan konsumen dan pengguna yang berhubungan dengan transformasi sistem kerja mereka untuk dijadikan software. Dimana kebutuhan pengguna sangat perlu diorganisasi dan disepakati bersama antara konsumen dan pengembang software. Sehingga proses requirement engineering manjadi bagian penting pada proses software engineering. Kesalahan dalam menentukan kebutuhan akan berakibat pada sebuah kegagalan pada proyek. Dalam proses requirement engineering hal yang pertama kali harus didapatkan adalah kebutuhan pengguna. Akan tetapi kebutuhan pengguna sangat sulit untuk dipahami dan dimengerti (Aida Azadegan, 2013).

Kebutuhan pengguna memiliki peran utama dalam proses pengembangan dan kebutuhan bisnis perangkat lunak. Dalam banyak kasus pemangku kepentingan yang memiliki perspektif dan harapan tentang masa depan sistem yang berbeda perlu berkolaborasi untuk memperjelas, menangkap dan mengungkap kebutuhan pengguna dengan cara yang efektif. Banyak pakar industri telah mengakui bahwa kerja sama antar pemangku kepentingan dalam lokakarya yang difasilitasi untuk mendefinisikan dan menjelaskan kebutuhan pengguna, merupakan salah satu hal yang paling sulit dalam pengembangan perangkat lunak (Aida Azadegan, 2013). Requirements engineering merupakan tugas yang cukup sulit 
bila dilakukan secara lokal, namun jauh lebih sulit ketika pemangku kepentingan lintas fungsional, budaya, bahasa dan zona waktu.

Dalam rangka mendapatkan kebutuhan pengguna yang tepat, perlu dilakukan kolaborasi antara pengembang dan seluruh pemangku kepentingan yang terlibat. Hal ini dapat dilakukan dengan melakukan kolaborasi. Ada beberapa aspek sosial yang perlu diperhatikan karena pada dasarnya hubungan sosial dan sharing knowledge merupakan salah satu aspek penting dalam melakukan requirement engineering (Risto Paavola, 2016). Hubungan sosial dan sharing knowledge sendiri merupakan salah satu pokok utama dalam melakukan kolaborasi terutama pada virtual team dimana masing-masing individu dalam tim terpisah secara geografis yang tidak memungkinkan untuk bertatap muka secara langsung. Hal tersebut sangat mempengaruhi cara dan model dalam mendapatkan kebutuhan pengguna pada virtual team, diantaranya dengan menggunakan pendekatan user-centered design dan wawancara.

Terdapat banyak tantangan yang sekaligus juga menjadi permasalahan dan kendala dalam proses virtual team pada aktivitas requirements engineering, yaitu: keragaman budaya pelanggan dan bisnis, berkurangnya tingkat kepercayaan (trust), kesulitan dalam mengelola konflik dan diskusi secara terbuka, kesulitan dalam mencapai kesepakatan bersama mengenai kebutuhan (Zowghi, 2002), beberapa tantangan dan permaslahan yang lain akan dijelaskan lebih detail dalam pembahasan makalah ini.

Salah satu tujuan dari literature review ini adalah mengulas cara-cara penggalian kebutuhan pada virtual team dan mengulas tantangan apa saja yang dihadapi untuk penggalian kebutuhan pada virtual team. Metodologi penulisan makalah ini melalui studi dari berbagai literatur yang relevan dengan topik, kemudian diulas dan menghasilkan pemaparan tentang cara penentuan kebutuhan terhadap virtual team.

Makalah ini terbagi atas 6 bagian dengan pandahuluan pada bagian 1. Bagian 2 metode penulisan studi literatur makalah ini. Bagian 3 menjelaskan hasil dari proses studi literatur dari beberapa penelitian sebelumnya. Diskusi terkait beberapa temuan dari studi literatur yang berhubungan dengan topik makalah ini dipaparkan dalam bagian 4. Kesimpulan dari penulisan makalah ini terdapat pada bagian 5 .

\section{Metode Penelitian (Methods)}

Metodologi yang digunakan dalam penulisan makalah ini adalah studi literatur yang berhubungan dengan metode-metode untuk mendapatkan user requirement pada virtual team dalam software engineering. Penulisan makalah ini terdiri dari beberapa tahapan. Tahapan dalam studi literatur ini dijelaskan pada sub bab berikut ini.

\subsection{Pencarian studi pustaka}

Sumber daftar pustaka yang digunakan dalam penulisan makalah ini dikumpulkan dari jurnaljurnal terkait tentang user requirement virtual team pada software engineering. Sumber pustaka didapatkan dengan cara mengunduh jurnal pada ScienceDirect, EmeraldInsight BPMJ, dan IEEE. Pencarian jurnal terkait dengan memasukkan kata kunci pada pencarian basis data jurnal tersebut. Kata kunci yang digunakan untuk pengumpulan sumber pustaka adalah "requirement engineering", "virtual team", dan "software engineering". Setelah mencari jurnal terkait, penulis juga memperhatikan kesesuaian sumber-sumber antara satu dengan yang lain, kesesuaian tersebut berkaitan dengan abstrak, heading, dan document statement pada sumber.

\subsection{Evaluasi studi pustaka}

Tujuan dari literature review requirement engineering terhadap virtual team pada proyek software engineering adalah untuk membuat studi ilmiah dengan memasukkan unsur evaluasi dan mengkritisi terhadap hal-hal yang pernah dikemukakan pada penelitian sebelumnya. Proses evaluasi studi pustaka dilakukan dengan 'skimming' yaitu membaca cepat sambil menangkap intisari sumber bacaan untuk memberikan arahan kepada penulis. Proses evaluasi juga dilakukan dengan 'paragraph statement', yaitu mencari kalimat yang terpenting dalam suatu paragraf. Evaluasi ini juga dilakukan untuk melihat apakah penulis pada sumber pustaka tersebut adalah orang yang benar-benar mempunyai otoritas di dalam permasalahan yang diangkat. Hal ini berguna untuk menjaga keakuratan sumber, 
metode, data, dan ketepatan penganalisaan penulis. Selain evaluasi sumber, kemutakhiran sumber juga perlu untuk dijaga. Pada literatur review ini, studi pustaka yang digunakan adalah penelitian tahun 20002021. Penulis mengangkat tema pada metode lama yang masih digunakan sampai saat ini.

\subsection{Analisis Studi pustaka}

Analisis studi pustaka yang dilakukan dengan cara summary (rangkuman). Summary ini dilakukan dengan menggabungkan pendapat dari penelitian satu dengan penelitian yang lain untuk mendapatkan hasil yang diinginkan sesuai tema yang diangkat.

\section{Hasil dan Pembahasan (Results and Discussions)}

\subsection{Hasil}

Sumber pustaka yang digunakan dalam literature review ini adalah beberapa makalah. Namun, sumber pustaka utama pada literature review ini terdapat 5 makalah setelah dilakukan evaluasi. Makalah tersebut di kelompokkan menjadi dua pembahasan utama, yaitu virtual team pada software engineering dan requirement engineering untuk virtual team. Sumber pustaka yang telah dikelompokkan tersebut diulas untuk menjadi bahan dalam pembahasan yang terdapat di dalam makalah. Berikut ini adalah hasil review studi pustaka:

P1: Corbitt (2001) membahas mengenai permasalahan-permasalahan dan tantangan apa saja dalam proses penggalian kebutuhan (Requirement Engineering) virtual domain dalam sudut pandang sosial dan budaya yang diimplementasikan pada software development oleh virtual team di Thai Software House (rumah pembuatan perangkat lunak) (Jo Hanisch, 2001).

P2: Sidhartha (2008) menyajikan bagaimana proses pengembangan perangkat lunak di Large Virtual Team (LVTs) dapat dikelola, sehingga sesuai dengan ISO 9001. Sesuatu yang baru dari penelitian ini adalah terdapat kelangkaan studi tentang penerapan proses berbasis pendekatan di organisasi virtual. Penelitian ini membahas kesenjangan dalam literatur dengan memeriksa bagaimana proses pengembangan perangkat lunak dalam organisasi virtual dapat secara resmi dikelola, sehingga sesuai dengan ISO 9001 (Sidhartha R. Das, 2008).

P3: Damian dan Zowghi (2002) melaporkan sebuah studi lapangan yang diamati tentang tantangan pada perkenalan Requirement Engineering oleh stakeholder yang tersebar pada geografis multi-situs organisasi. Tujuannya adalah untuk memeriksa praktik Requirement Engineering dalam pengembangan perangkat lunak global, untuk merumuskan rekomendasi perbaikan serta memberikan arahan metode dan alat bagi penelitian di masa depan. Peneliti telah membangun sebuah model, seberapa jauh komunikasi dan pengetahuan manajemen, keragaman budaya dan perbedaan waktu berdampak negatif pada pengumpulan kebutuhan, negosiasi dan spesifikasi. Hasil penelitian menunjukkan bahwa aspek seperti kurangnya pemahaman umum kebutuhan, kesadaran bekerja sama dalam konteks lokal berkurang, tingkat kepercayaan dan kemampuan untuk berbagi berkas kerja secara signifikan menjadi tantangan kolaborasi yang efektif dari sedikitnya stakeholder dalam proses negosiasi sekumpulan kebutuhan yang memenuhi didistribusikan kepada pelanggan secara geografis. Peneliti juga merekomendasikan untuk meningkatkan praktik Requirement Engineering dalam konteks tim virtual (Zowghi, 2002).

P4: Yovchevs (2012) mengadopsi pendekatan user-centered design dan menjelajahi kebutuhan pengguna pertama yaitu peneliti di bidang lingkungan yang bekerja pada distributed research projects untuk diseminasi kolaboratif, pertukaran dan bekerja dengan data spatio-temporal. Hasil penelitian menunjukkan bahwa desain utama sistem dipengaruhi oleh sifat dan jenis data pekerjaan pengguna. Dari perspektif pengguna akhir, konversi optimal file besar data spatio-temporal untuk menyebarkan informasi lebih lanjut, akurasi konversi, organisasi konten dan keamanan memiliki peran penting untuk keefektifan geo-kolaborasi (Zornitza Yovcheva, 2013).

P5: Edwards dan Sridhar (2003) menguji praktik Requirement Engineering dalam pengembangan perangkat lunak global, dan merumuskan rekomendasi untuk perbaikan serta memberikan arah bagi penelitian di masa depan yaitu sebuah model bagaimana komunikasi jarak jauh dan manajemen 
pengetahuan, keragaman budaya dan perbedaan-perbedaan waktu berdampak negatif terhadap pengumpulan kebutuhan, negosiasi dan spesifikasi-spesifikasi. Hasil penelitian menunjukkan bahwa aspek seperti kurangnya pemahaman umum kebutuhan, berkurangnya kesadaran bersama dari konteks lokal yang bekerja, tingkat kepercayaan dan kemampuan untuk berbagi dokumen kerja menjadi tantangan signifikan dalam efektifitas kolaborasi stakeholder yang terpencil dan negosiasi kebutuhan yang terpenuhi terhadap geografis didistribusikan pelanggan (Sridhar, 2003).

Hasil evaluasi studi pustaka tersebut di analisis dengan cara summary (rangkuman). Hasil analisis studi pustaka tersebut membahas tentang teknik kolaborasi pada virtual team dan permasalahanpermasalahan untuk penggalian kebutuhan pada virtual team sebuah proyek software engineering. Masalah utama yang sering terjadi pada virtual team adalah komunikasi yang disebabkan oleh perbedaan budaya, zona waktu, dan keahlian masing-masing tim. Teknik yang paling banyak digunakan dalam penggalian kebutuhan pada virtual team adalah teknik kolaborasi, dimana para pemangku kepentingan berkolaborasi untuk menggali kebutuhan dengan bantuan media/teknologi. Beberapa cara yang digunakan untuk menggali kebutuhan user pada virtual team adalah dengan cara wawancara melalui telekonferensi, survei secara daring, kuisioner daring, dan lainnya.

\subsection{Pembahasan}

\subsubsection{Virtual Team pada Software Engineering}

Software engineering dapat disaksikan untuk sebuah transisi dari bentuk format pengembangan lokasi tradisional ke format dimana tim perangkat lunak secara global berkolaborasi melintasi perbatasan nasional (Zowghi, 2002). Hal ini menandakan bahwa sebuah proyek software engineering tidak terbatas oleh letak geografi atau tempat yang sama. Hal tersebut dapat menjadi peluang dan tantangan bagi sebuah proyek software engineering. Salah satu tantangan pada virtual team dibandingkan tim lokal adalah cara virtual team secara global jarang sekali mengadakan pertemuan face to face (Sridhar, 2003). Penggunaan virtual team dalam sebuah proyek software engineering merupakan salah satu adaptasi struktural sehingga memungkinkan perusahaan untuk menggunakan sumber daya yang diperlukan lebih efisien (Sidhartha R. Das, 2008).

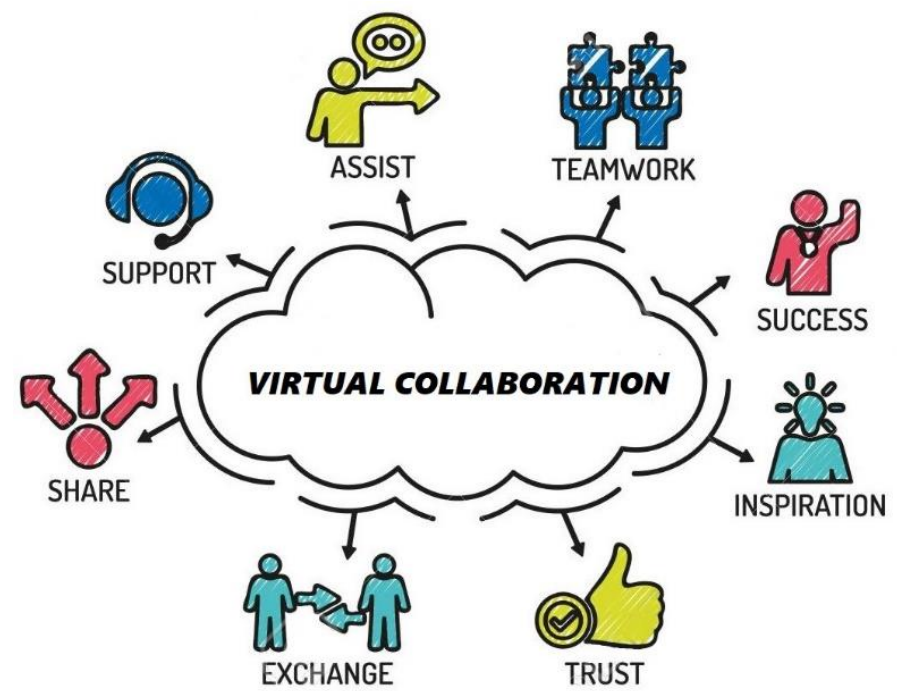

Gambar 1: Ilustrasi Virtual Collaboration (Kuttappa, 2020)

Salah satu studi kasus pada Global Development System (GDS) yang merupakan sebuah perusahaan multi-situs besar, yang memiliki kantor pusat di Amerika Serikat dan tim global mengembangkan aplikasi perangkat lunak (Zowghi, 2002). Virtual team menghubungkan komputer dan teknologi komunikasi lintas batas negara. Dalam studi kasus ini, sebuah proyek dimana pengumpulan kebutuhan, perencanaan strategis dan negosiasi kebutuhan, pengembangan, pengujian, dan integrasi terjadi pada 
struktur yang didistribusikan. Perangkat lunak yang dihasilkan adalah produk line software, kakakteristik oleh pengiriman serangkaian rilis. Setiap rilis sekitar 8000KLOC, waktu pembangunan antara 12-18 bulan, dengan aprox, dan 120 pengembang full time yang terlibat yang merupakan perusahaan perangkat lunak, pengembang pelanggan sendiri menggunakan sistem untuk mengembangkan perangkat lunak. Fitur untuk rilis baru yang berasal dari analisis rilis saat ini dan strategi bisnis yang sedang berlangsung. Penelitian melaporkan proyek-proyek yang dikembangkan antara Amerika Serikat dan India serta benua lain seperti Asia dan Eropa.

Studi kasus lain tentang Global Virtual Team (GVT) juga memberikan hasil yang menarik terhadap penilaian virtual team, karena era globalisasi software menghasilkan (Cristina B. Gibson, 2021):

1. Aktivitas pengembangan software yang melibatkan teknologi terbaru dan negara maju.

2. Pengembangan software bergeser dari tren format lokal tradisional menjadi tim global virtual yang menembus batas suatu negara.

3. Telekomunikasi dalam skala yang besar dan bermunculan perusahaan software dengan berbagai macam kelompok pengembangan perangkat lunak di berbagai negara di dunia melalui media virtual yang berfungsi sebagai media komunikasi dan interaksi pekerjaan mereka.

Salah satu keuntungan pengembangan software dengan memanfaatkan global virtual team di India dan China adalah biaya yang murah. Sebagai contohnya Motorola yang memiliki pusat pengembangan software di seluruh dunia, mereka menggunakan tenaga luar perusahaan (outsource) untuk melakukan aktivitas pengembangan software kepada kontraktor yang berada di luar negaranya. Namun, global virtual team (GVT) berdampak pada munculnya berbagai permasalahan yang tidak berhubungan dengan tim tradisional.

Beberapa faktor yang mendorong kecenderungan tim virtual: termasuk merger, akuisisi perusahaan, perampingan dan peningkatan penggunaan teknologi baru. Sebagai hasil dari perampingan pada skala global dengan organisasi, banyak keahlian mereka menjadi tersebar di seluruh organisasi di sejumlah negara atau wilayah, sehingga tim virtual dapat dibentuk, dan tim virtual ini mungkin termasuk anggota potensial dari berbagai budaya yang berbeda. Tim virtual telah berkembang dari status "ide yang baik" menjadi "strategi penting" bagi banyak organisasi. Virtual team merupakan kelompok orang yang bekerja sama erat meskipun mereka terpisahkan oleh jarak, bahkan benua. Mereka lebih didefinisikan sebagai "jaringan sementara profesional independen, terpisah oleh jarak geografis, temporal dan psikologis, yang penggunaan alat-alat telekomunikasi untuk komunikasi bisnis adalah saling bergantung, untuk memenuhi kebutuhan bisnis keterampilan berbagi dan bekerja untuk memenuhi tujuan bersama" tim virtual ditandai oleh anggota yang terisolasi secara fisik, yang berinteraksi terutama melalui penggunaan teknologi komunikasi elektronik dan yang jarang atau tidak pernah bertemu tatap muka sebagaimana kondisi pandemic covid-19 saat ini (Ashley Whillans, 2021).

\subsubsection{Kolaborasi pada Virtual Team}

Penentuan kebutuhan dengan kolaborasi pada tim lokal, juga dapat digunakan untuk penentuan kebutuhan terhadap virtual team (Sridhar, 2003). Kolaborasi pada virtual team dilakukan dengan berbagai dukungan media. Beberapa media groupware yang dapat digunakan seperti $e$-mail, berbasis teks dan audio chatting, alat konferensi video, dan whiteboard yang memberikan kesempatan untuk memfasilitasi pendistribusian komunikasi dan kerja kolaboratif (Zornitza Yovcheva, 2013). Banyak peneliti menggunakan teknik kolaborasi untuk menggali kebutuhan pengguna pada virtual team.

\subsubsection{Metode-metode yang digunakan untuk mendapatkan User Requirement pada Virtual Team}

Requirement Engineering (RE) merupakan sebuah tugas yang cukup sulit dilakukan pada tim lokal apalagi penentuan fungsional spesifikasi kebutuhan pada lintas kelompok stakeholder, lintas budaya, bahasa dan batasan zona waktu (antar negara, benua dan samudera) (Zowghi, 2002), (J.S. Gallego, 2021). Namun, penelitian-penelitian yang terdapat pada studi literatur telah menerapkan metode-metode yang digunakan untuk penentuan kebutuhan. Dari hasil studi literatur, metode yang digunakan beberapa peneliti untuk menentukan kebutuhan untuk virtual team pada software engineering, yaitu: 


\section{Pendekatan User-Centered Design}

Pendekatan user-centered design yaitu pendekatan yang digunakan untuk bidang lingkungan yang bekerja pada distributed research projects untuk diseminasi kolaboratif, pertukaran dan bekerja dengan data spatio-temporal. Pendekatan ini terdiri dari beberapa tahapan. Tahapan dalam membuat user requirement dengan pendekatan ini juga dibagi menjadi beberapa langkah, yaitu:

\section{a. Menentukan User Group}

User group ditentukan berdasarkan bidang keahlian dari pengguna. Peserta dalam proyek multidisiplin dilakukan oleh tim tersebar dibutuhkan untuk tetap berhubungan. Upaya ini membutuhkan dan /atau dapat difasilitasi oleh kerja kolaboratif dalam multi-user lingkungan yang mendukung visualisasi dan penyebaran data spatio-temporal dimana para peneliti akan dapat bertukar pengetahuan dan mengontekstualisasikan pekerjaan mereka.

\section{b. Questionnaire dan Online Survey}

Sebuah survei online digunakan sebagai instrumen untuk mengumpulkan data dan mengelola kuesioner. Kuesioner dibagikan kepada pengguna potensial melalui hyper-link yang dihasilkan. Tujuan utamanya adalah untuk mengumpulkan informasi kualitatif tentang pengguna utama pada demografi kunci, karakteristik fisik dan psikologis, pekerjaan mereka dengan Data spatio-temporal, cara saat ini dan kebutuhan untuk kolaborasi. Informasi yang dikumpulkan harus berkaitan dengan beberapa kategori atribut, yaitu: 1) Karakteristik pengguna dasar terkait dengan demografi, latar belakang pengetahuan dan pendidikan, domain keahlian, serta pengalaman dengan informasi teknologi dan bola berbasis laman virtual; 2) Bekerja sekarang dengan data spatio-temporal dan peta animasi, dan masalah dengan penyebaran mereka; 3) Kolaborasi kerja, frekuensi dan tujuan komunikasi pada proyek-proyek penelitian; 4) Preferensi pengguna terhadap alat kolaboratif dan cara untuk penyebaran data spatiotemporal; 5) Informasi pribadi untuk kontak lebih lanjut dan kemauan untuk berpartisipasi dalam tahap lain dari penelitian.

\section{c. Focus Group Setup}

Pada tahap ini, user requirement diidentifikasi terhadap data spatio-temporal dan informasi yang diterjemahkan ke dalam elemen desain tertentu melalui pengembangan kebutuhan. Pada dasarnya, setiap ruang virtual memiliki tampilan peta (Google Earth plug-in), yang disinkronkan untuk semua audien melalui tombol kontrol. Di sisi kanan halaman web, fungsi dipisahkan dalam tiga tab utama: Tab Chatting, dimana pengguna dapat mengirim pesan dan menerima umpan balik sistem dan feedthrough, kemudian Tab Maps, dimana pengguna dapat mengunggah user-generated peta / peta animasi, komentar dan metadata dan Tab User, dimana pengguna dapat memantau peserta dalam diskusi dan mengirim undangan sementara untuk anggota eksternal tim.

\section{d. Collaborative Usability Tests Setup}

Tahap implementasi prototipe dilakukan oleh pengembang perangkat lunak dan diikuti oleh enam tes usability kolaboratif berbasis skenario. Tujuan utama dari percobaan adalah untuk mensimulasikan waktu yang sama / tempat situasi geo-kolaboratif didistribusikan secara nyata, berbeda dan untuk mengamati bagaimana potensi pengguna bekerja dengan prototipe yang dikembangkan. Tes usability berlangsung di laboratorium usability, dilengkapi dengan komputer (dengan layar logging), kamera video, mikrofon nirkabel. Sedangkan ruang kedua, dilengkapi dengan kamera video ponsel dan komputer. Sebuah unit segi empat digital di laboratorium usability digunakan untuk menggabungkan dan mensinkronkan masukan dari semua sumber. Secara total, 12 pengguna perwakilan berpartisipasi dalam tes, dalam kelompok dua. Para peserta di masing-masing kelompok tidak mengenal satu sama lain sebelum sesi tes (J.S. Gallego, 2021).

\section{Menggunakan metode pengumpulan data melalui wawancara}

Proses ini dilakukan secara mendalam dengan sistem analis dari Thai Software House. Pertanyaan terbuka-tertutup sehingga sistem analis dapat secara bebas untuk menjelaskan pengalamannya dan permasalahan yang dihadapi (Jo Hanisch, 2001). Salah satu alasan yang menyebabkan kenapa dibutuhkan virtual team dalam penggalian kebutuhan pada studi kasus yang terjadi di Thai Software 
House, karena terdapat budaya "High Power Distance" (Geert Hofstede, 2010) dimana pewawancara (interviewer) memperlakukan klien (yang diwawancarai) selayaknya seorang bos. Sehingga muncul wawancara dengan cara virtual (jarak jauh), namun tidak mungkin jika wawancara secara virtual dilakukan kepada pengguna satu per satu, maka dibentuklah struktur organisasi yang disesuaikan dengan budaya yang ada di Thailand. Dari struktur tersebut terdapat masing-masing perwakilan top level manajer, middle manajer hingga klien atau pengguna (Toews, 1998).

\subsubsection{Permasalahan dalam virtual team pada software engineering}

Permasalahan yang paling banyak terhadap penggalian kebutuhan pada virtual team dalam proyek software engineering adalah masalah komunikasi. Temuan menekankan masalah utama adalah komunikasi dan koordinasi, kegiatan yang penting selama fase awal perencanaan strategis, pengumpulan kebutuhan, analisis dan negosiasi (Zowghi, 2002), (J.S. Gallego, 2021).

Beberapa tantangan permasalahan yang menjadi kesulitan tersendiri dalam melaksanakan aktivitas RE (Zowghi, 2002):

1. Keragaman budaya pelanggan dan bisnis.

2. Mencapai partisipasi yang tepat dari pengguna sistem dan petugas lapangan.

3. Kurangnya komunikasi informal dan berkurangnya kesadaran dari konteks kerja lokal.

4. Berkurangnya tingkat kepercayaan (trust).

5. Kesulitan dalam mengelola konflik dan berdiskusi terbuka tentang kepentingan.

6. Kesulitan dalam mencapai pemahaman bersama mengenai kebutuhan (requirement).

7. Pertemuan pengambilan keputusan menjadi tidak efektif.

8. Penundaan (delay).

Mengelola kebutuhan dari basis user yang besar adalah masalah mendasar dalam RE, apalagi pada virtual team yang terdistribusi geografis memperburuk masalah besar yang terkait dengan dan bertentangan menetapkan kebutuhan yang dibuat oleh penggunaan sistem di pasar yang beragam, nasional, dan budaya organisasi. Beberapa faktor yang mempengaruhinya adalah pertama, bahasa user merupakan faktor penting yang secara langsung berdampak pada kegiatan seperti elisitasi kebutuhan dan validasi, hambatan bahasa mempengaruhi transfer pengetahuan dari kebutuhan untuk personil lapangan dan pengembang.

Tantangan tambahan muncul di beberapa tingkatan: tren pasar mungkin berbeda dengan segmen pasar, perbedaan budaya nasional sering menyebabkan kebutuhan bermakna dalam konteks keyakinan budaya tertentu dan nilai-nilai (misalnya beberapa negara mungkin menghargai stabilitas dan meminta kebutuhan hanya karena itu telah dirilis sebelumnya, ketika klien lain mendukung fitur baru dalam sistem untuk kemajuan terus menerus). Selanjutnya, jarak meningkatkan kemungkinan keragaman dalam budaya perusahaan, yaitu penggunaan sistem dalam metodologi yang ada.

Faktor-faktor ini berkontribusi pada virtual team dalam menghadapi masalah mendasar dalam RE. Kebutuhan yang dinyatakan dengan menggunakan beragam terminologi dan tingkat detail, sehingga membuat analisis konflik, dan redundansi yang sulit. Ini merupakan salah satu penyebab tantangan paling signifikan dalam organisasi global ini: prioritas dan negosiasi kebutuhan pelanggan untuk rilis tertentu, dalam konteks kebutuhan bisnis dan strategi yang spesifik dan sumber daya yang terbatas pembangunan. Kebutuhan berdiri sebagai tantangan nyata karena sulitnya membuat trade-off pada daftar besar kebutuhan yang beragam dalam menghadapi ketidakpastian.

Sebuah model mengidentifikasi empat masalah utama dari distribusi geografis pemangku kepentingan, masalah umum ini telah menciptakan kesulitan tertentu dalam melakukan kegiatan RE (Zowghi, 2002), (J.S. Gallego, 2021):

1. Komunikasi yang Tidak Memadai. Jarak menjadi hambatan komunikasi informal dan tatap muka, dan komunikasi para pemangku kepentingan tergantung pada kualitas menggunakan alat komunikasi elektronik sinkron atau asinkron. Dalam penelitian ini, kelompok kepentingan (pelanggan, manajemen bisnis, dan pengembang) tidak berkomunikasi secara efektif dan masing-masing berusaha untuk mengerahkan kekuasaan dan pengaruh atas orang lain. 
2. Manajemen Pengetahuan. Informasi kuantitatif tentang kebutuhan dari berbagai sumber di lokasi pelanggan jauh tidak tepat bersama dengan pengembang. Selain itu, dengan menyalurkan informasi tentang kebutuhan strategi bisnis untuk pengembang melalui pemangku kepentingan kunci, manajer pengembangan, jarak dieksploitasi untuk memperkuat posisi tertentu kekuasaan dalam organisasi.

3. Keragaman Budaya. Perbedaan bahasa pemangku kepentingan dan budaya nasional mempengaruhi kolaborasi global. Sama pentingnya dalam penelitian ini adalah dampak dari perbedaan budaya organisasi dan fungsional. Tidak hanya situs pengendalian mengembangkan budaya organisasi mereka sendiri, tetapi juga jarak lebar kesenjangan antara departemen fungsional yang berbeda dari organisasi (pemasaran, manajemen bisnis, dan pengembangan). Hal ini memiliki dampak yang signifikan pada pencapaian pemahaman bersama dan negosiasi kebutuhan.

4. Perbedaan Waktu. Distribusi besar pemangku kepentingan di 5 benua diperkenalkan perbedaan zona waktu yang besar dan memungkinkan sedikit tumpang tindih tersedia untuk kolaborasi sinkron. Oleh karena itu, saluran asinkron yang dominan dalam komunikasi, dilengkapi dengan panggilan telekonferensi. Pertemuan sinkron di seluruh benua selalu canggung untuk setidaknya satu situs terlalu lambat, dan melibatkan seseorang harus berkompromi pada jadwal kerja mereka.

\section{Kesimpulan (Conclusion)}

Kolaborasi virtual team yang memungkinkan format dimana tim proyek perangkat lunak dapat bekerja melintasi batas geografis menjadikan sebuah proyek software engineering dapat dikerjakan secara global dan memungkinkan perusahaan untuk memanfaatkan sumber daya dengan lebih efisien. Terdapat satu studi kasus dimana global virtual team (GVT) memberikan hasil menarik terhadap penilaian virtual team, hal ini dikarenakan beberapa faktor berikut: Aktivitas pengembangan software yang melibatkan teknologi terbaru dan negara maju, pengembangan software bergeser dari tren format lokal tradisional menjadi tim global virtual yang menembus batas suatu negara, dan telekomunikasi dalam skala yang besar dan bermunculan perusahaan software dengan berbagai macam grup pengembangan perangkat lunak di berbagai negara di dunia melalui media virtual yang berfungsi sebagai media komunikasi dan interaksi pekerjaan mereka. Salah satu contoh pemanfaatan global virtual team dalam software engineering adalah seperti yang dilakukan oleh Motorola yang memiliki pusat pengembangan software di berbagai belahan dunia dan juga menggunakan jasa kontraktor yang berada di luar negaranya.

Dalam melakukan proses requirement engineering, virtual team menggunakan berbagai macam alat dan media media groupware yang dapat digunakan seperti e-mail, berbasis teks dan audio chatting, alat konferensi video, dan whiteboard yang memberikan kesempatan untuk memfasilitasi pendistribusian komunikasi dan kerja kolaboratif. Hal ini juga menunjukkan pentingnya peran teknologi dalam kolaborasi pada virtual team.

Metode-metode yang digunakan untuk requirement engineering dari hasil review studi pustaka ini, antara lain dengan menggunakan pendekata user-centered design dan metode pengumpulan data melalui wawancara secara mendalam dengan analis sistem seperti yang dilakukan oleh Thai Software House. Global virtual team memiliki beberapa tantangan yang harus dihadapi dalam aktifitas requirement engineering, antara lain: Keragaman budaya pelanggan dan bisnis, pencapaian partisipasi yang tepat dari pengguna sistem dan petugas lapangan, kurangnya komunikasi informal dan berkurangnya kesadaran dari konteks kerja lokal, berkurangnya tingkat kepercayaan (trust), kesulitan dalam mengelola konflik dan berdiskusi terbuka tentang kepentingan, kesulitan dalam mencapai pemahaman bersama mengenai kebutuhan (requirement), pertemuan pengambilan keputusan menjadi tidak efektif, dan penundaan (delay). 
Proses penggalian kebutuhan merupakan tahapan krusial dalam pengembangan software tanpa memperhatikan apakah pengembangan tersebut lokal atau global (virtual). Untuk menghadapi semua tantangan pada proses pengembangan software agar tetap seimbang, maka manajer proyek perlu untuk membuat struktur pengambilan data formal dan perlu untuk menciptakan lingkungan yang mendukung komunikasi terbuka dan perbedaan budaya dalam pengembangan software secara virtual. Sehingga, tidak hanya akan membangun sistem dengan benar, namun sistem yang benar akan terbangun. Pemanfatan global virtual team dengan biaya yang lebih murah daripada tim lokal tradisional. Terdapat beberapa faktor yang memberikan pengaruh terhadap kualitas dan kinerja dari GVT, salah satu yang paling kritis (sangat perlu diperhatikan) adalah tahap pendefinisian kebutuhan (requirement definition) karena akan memberikan dampak besar pada kualitas dari produk software dan membutuhkan komunikasi yang efektif antara tim proses bisnis dengan tim sistem analis.

Untuk penggalian kebutuhan pada virtual team, jarak memiliki dampak yang signifikan pada kolaborasi yang melibatkan antar geografis kelompok fungsional berbeda dalam negosiasi kebutuhan dari pasar pelanggan yang beragam. Ada kebutuhan untuk penelitian dengan tujuan mengembangkan proses rekayasa kebutuhan khusus untuk pengembangan sistem dalam organisasi yang multi-situs, untuk menghadapi tantangan yang telah peneliti identifikasi. Penelitian-penelitian yang ada telah banyak melakukan penggalian kebutuhan pada virtual team dengan teknik kolaborasi. Semua pemangku kepentingan bekerja sama untuk menentukan kebutuhan dari berbagai bidang ilmu, lokasi, dan keahlian. Kolaborasi virtual ini memiliki banyak tantangan karena adanya perbedaan antara budaya, lokasi, keahlian, dan waktu.

\section{Ucapan Terima Kasih (Acknowledgement)}

Penulis sangat berterima kasih kepada seluruh tim atas kerjasamanya, khususnya kepada Bapak Faizal Mahananto selaku pembimbing yang memberikan masukan dan bimbingan sehingga bisa menyelesaikan makalah ini.

\section{Daftar Pustaka}

Aida Azadegan, K. N. P. a. P. S., 2013. Applying collaborative process design to user requirements elicitation: A case study. Computers in Industry, 64(7), pp. 798-812.

Ashley Whillans, L. P. A. T., 2021. Experimenting during the shift to virtual team work: Learnings from how teams adapted their activities during the COVID-19 pandemic. Information and Organization, Volume 31, pp. 1-12.

Cristina B. Gibson, S. V. G., 2021. A Tale of Two Teams: Next Generation Strategies for Increasing the Effectiveness of Global Virtual Teams. Organizational Dynamics, 50(1).

Geert Hofstede, G. J. H. a. M. M., 2010. Cultures and Organisations - Software of the Mind. United States: McGraw.

J.S. Gallego, I. O.-M. J. R. R., 2021. Main challenges during project planning when working with virtual teams. Technological Forecasting \& Social Change, Volume 162, pp. 1-10.

Jo Hanisch, T. T. a. B. C., 2001. Exploring The Cultural and Social Impacts on The Requirements Engineering Processes. Journal of Systems and Information Technology, 5(2), pp. 1-20.

$\begin{array}{lcrcrl}\text { Kuttappa, } & \text { S., } & 2020 . & \text { Virtual } & \text { Collaboration. } & \text { [Online] } \\ \text { Available } & \text { at: } & \text { https://shoury01.medium.com/virtual-collaboration-9a9290fe1a6 }\end{array}$ [Accessed 15 Agustus 2021].

Risto Paavola, P. H., 2016. Antecedents for successful collaboration in requirements engineering. VINE Journal of Information and Knowledge Management Systems, 46(3), pp. 353-370. 
Sidhartha R. Das, U. Y. a. C. C., 2008. Using ISO 90003 for software "design and development" in large virtual teams. Industrial Management \& Data Systems, 108(6), pp. 775-793.

Sridhar, H. E. a. V., 2003. Analysis of The Effectines of Global Virtual Teams inf Software Engineering Projects. Hawaii International Conference on System Sciences, p. 9.

Toews, B. a. M. R., 1998. Culture Shock - Succeed in Business - Thailand. Singapore: Times Book International.

Zornitza Yovcheva, C. P. J. v. E. a. B. K., 2013. User requirements for geo-collaborative work with spatio-temporal data in a web-based virtual globe environment. Applied Ergonomics, 44(6), pp. 929939.

Zowghi, D. D. a. D., 2002. The impact of stakeholders' geographical distributiononmanaging requirements in a multi-site organization. International Conference on Requirements Engineering, Sydney. 